\title{
SODELOVANJE SLOVENSKE VOJSKE V MEDNARODNIH OPERACIJAH IN NA MISIJAH V LUČI ZUNANJE POLITIKE REPUBLIKE SLOVENIJE
}

Povzetek Slovenska vojska mora biti v okviru svojih nalog sposobna izvesti vojaško obrambo države, izpolnjevati mednarodne obveznosti, sodelovati v mednarodnih operacijah in na misijah (MOM) ter v sistemu varstva pred naravnimi in drugimi nesrečami.

Odločitev države o sodelovanju v MOM je v številnih državah precej zapletena zaradi različnih in med seboj nasprotujočih si političnih pogledov ter ustavnih rešitev.

Republika Slovenija aktivno sodeluje v MOM od leta 1997. Tako želi skladno s svojimi zmožnostmi in interesi prispevati k vzpostavitvi mednarodnega miru in stabilnosti, predvsem v svoji soseščini, jugovzhodni Evropi.

Sodelovanje RS bo imelo v MOM predvsem funkcije varnostnih in zunanjepolitičnih interesov ter ciljev RS. SV bo zato v MOM sodelovala predvsem z višjo stopnjo tveganja, ki zahteva poudarjeno vojaško silo, in ne več predvsem z operacijami, ki so bližje policijskim nalogam.

Ključne besede

Abstract

\section{Zunanja politika, mirovne operacije in misije, Slovenska vojska.}

Within its scope of tasks, the Slovenian Armed Forces (SAF) should be capable of providing military defence of the country, fulfilling international obligations, and participating in international operations and missions (IOM) as well as in the system of protection against natural and other disasters.

In a number of countries, the decision to take part in IOMs is a rather complicated one, due to the versatile and contradictory political views and constitutional solutions. The Republic of Slovenia (RS) has been actively participating in IOM 
since 1997. This is its way of contributing to the establishment of international peace and stability, especially in its neighbourhood, the South-eastern Europe.

The IOM engagement of the RS will thus be mainly marked by security and foreign policy interests and will no longer include operations closer to police tasks, but rather participation in IOM with a higher level of risks requiring enhanced military force.

\section{Keywords Foreign policy, peace operations and missions, Slovenian Armed Forces.}

Uvod Sodobno varnostno okolje je zaradi delovanja številnih dejavnikov dinamično in spremenljivo ter zaznamovano s kriznimi pojavi. Negotovost in nestabilnost na kriznih območjih povzročata izzive, tveganja in grožnje pri delovanju akterjev mednarodne skupnosti. Stabiliziranje razmer na območju krize zahteva usklajeno in celovito načrtovanje ter uporabo razpoložljivih političnih, civilnih in vojaških sredstev. Odločitev o sodelovanju nacionalnih zmogljivosti mora biti podprta z jasno opredeljeno izhodno strategijo in cilji, s katerimi so določene bistvene naloge pri določanju zunanjepolitičnih prednostnih nalog. RS upošteva sedanje stanje in možen razvoj mednarodnih političnih, gospodarskih in varnostnih razmer v Evropi ter svetu in izhaja iz tistih vrednot, interesov ter ciljev, ki so temeljni za razvoj slovenskega naroda in slovenske države. RS se pri tem zaveda, da je ta razvoj zagotovljen le v razmerah trajnega miru in stabilnosti v Evropi ter svetu. V mednarodnih odnosih se RS zavzema za mirno reševanje sporov in zavrača uporabo sile. Podpira nadzor oboroževanja, razoroževanja in neširjenja orožja za množično uničevanje.

SV z aktivnim sodelovanjem v MOM uresničuje svoje razvojne cilje ter izpolnjuje dodeljene obveznosti v mednarodnih organizacijah (ZN, Nato, EU in OVSE). SV s sodelovanjem v MOM podpira in krepi razvoj nacionalnih zmogljivosti. Sodelovanje SV v MOM obsega poleg sodelovanja tudi zagotavljanje podpore diplomatskim in civilnim službam v okviru mednarodnih reševalnih operacij oziroma intervencij.

Vključevanje SV v prve MOM je bila prvotno politična odločitev, ki je bila sprejeta hitro, brez celovite strokovne analize in pod velikim vplivom naše želje po vključitvi v Nato.

Hkrati se poraja vprašanje, ali SV sodeluje v MOM zaradi potrebe zunanje politike ali zaradi nacionalne varnosti. Sodelovanje v MOM je zlasti pomembno za SV, saj tako urjenje omogoča hiter napredek pri vzpostavljanju bojne pripravljenosti, ki je pomembna tudi za nacionalno varnost, in zaradi urjenja posameznih situacij, $\mathrm{v}$ katerih se lahko znajdejo oborožene sile ter jih ni mogoče simulirati v drugačnih pogojih urjenja. V prispevku bom poskušal odgovoriti na vprašanji, kakšna je vloga SV pri uresničevanju zunanje politike RS in ali je SV verodostojna partnerica v izvrševanju zunanje politike RS, ter izhajal iz predpostavke, da zahteva vključevanje SV v MOM politični konsenz. 
V prispevku bom predstavil povezanost slovenske zunanje politike, pri kateri se kot instrument delovanja pojavlja SV. Zanima me odnos med zunanjo politiko RS in SV. Poskušal bom ugotoviti, ali obstajajo nacionalni cilji zunanje politike glede sodelovanja SV v MOM ali zgolj sledimo ciljem mednarodnih varnostnih organizacij. Predstavil bom temeljne strateške akte, ki opredeljujejo sodelovanje SV v MOM.

V prispevku bom sledil predvsem tem ciljem:

- predstavitev temeljnih izhodišč zunanje politike RS;

- predstavitev in klasifikacija MOM s poudarkom na operacijah, pri katerih je mogoče sodelovanje SV;

- analiza političnih in varnostnih razlogov za vključevanje v te operacije;

- predstavitev normativno-pravne ureditve kolektivne varnosti glede na temeljne dokumente s področja MOM v RS;

- vključevanje SV v izpolnjevanje obveznosti, ki izhajajo iz članstva RS v mednarodnih organizacijah.

\section{METODE}

Za opis značilnosti MOM in zunanje politike RS sem pri pripravi prispevka izbral metode proučevanja, analiziranja in primerjanja različne domače in tuje strokovne literature, aktov vodenja in poveljevanja ter analiz sklepov Vlade RS in zaključnih poročil iz posameznih mirovnih operacij. Kot dopolnilno empirično raziskovalno metodo za oblikovanje nekaterih svojih mnenj in sklepov sem uporabil metodo razgovora z nekaterimi strokovnimi izvajalci vodenja in poveljevanja v SV. V sklepu prispevka sem uporabil metodo raziskovanja s soudeležbo v procesu sprejemanja odločitev o napotitvi vojakov SV v mirovne operacije, s spremljanjem v fazah priprav in izvedbe aktivnosti ter $\mathrm{z}$ analiziranjem po koncu delovanja $\mathrm{v}$ mirovni operaciji.

Določeno omejitev pri izvedbi naloge so predstavljale omejene možnosti zbiranja posameznih podatkov o izvajanju MOM, ki so se jih udeležili posamezniki, enote in poveljstva SV, saj so ti podatki označeni z določeno stopnjo tajnosti.

\section{ZUNANJA POLITIKA RS}

Osnovne vrednote RS so zapisane v Ustavi RS, poleg te pa delovanje naše države na zunanjepolitičnem področju določajo še Zakon o zunanjih zadevah (ZZZ-1UPB-1) iz leta 2001, Temeljna ustavna listina o samostojnosti in neodvisnosti RS, Deklaracija o zunanji politiki RS, Resolucija o izhodiščih zasnove nacionalne varnosti RS, Resolucija o strategiji nacionalne varnosti RS iz let 2001 in 2010 ter dokumenta Primerna zunanja politika in Obrambna strategija RS.

Deklaracija o zunanji politiki RS (Uradni list RS, št. 108/1999) (v nadaljevanju Deklaracija) navaja, da je stabilnost Jugovzhodne Evrope (v nadaljevanju JVE) v življenjskem interesu RS, in prav ta prostor je tisti del Evrope, v katerem se mora 
RS skupaj s svojimi strateškimi partnerji uveljavljati kot pomemben mednarodni dejavnik. Aktivna vloga Slovenije v tem prostoru, zlasti v Bosni in Hercegovini, Črni gori in pri reševanju t. i. kosovskega vprašanja, je Slovenijo uveljavila kot pomembnega partnerja Nata in EU ter jo, skupaj z njeno dejavnostjo v Varnostnem svetu (VS) OZN, potrdila kot verodostojnega partnerja pri urejanju razmer v tem delu Evrope.

Politični, varnostni, gospodarski in drugi interesi ter razlogi zahtevajo, da je RS aktivna v JVE in zato dejavno podpira prizadevanja ter pobude mednarodne skupnosti za stabilizacijo in razvoj tega območja. V Paktu stabilnosti za JVE Republika Slovenija sodeluje skupaj z EU in drugimi udeleženkami Pakta, s posebnim poudarkom na gospodarskih projektih, vprašanjih varstva človekovih pravic, manjšin in na humanitarnem področju pri odpravljanju posledic vojne. V njenem interesu je, da razvija odnose z obema entitetama Bosne in Hercegovine (Federacijo in Republiko Srbsko) ob hkratni čvrsti podpori uresničevanju Daytonskega sporazuma in da nadaljuje razvoj odnosov z Makedonijo, Albanijo in drugimi državami regije. RS se z aktivno vlogo in podporo demokratičnim procesom $v$ tem prostoru uveljavlja kot pomemben in verodostojen partner mednarodne skupnosti pri urejanju razmer v tem delu Evrope.

Slovenska zunanja politika temelji na ohranjanju slovenske nacionalne identitete in hkratni odprtosti v svet. Uspešna zunanja politika mora biti učinkovit instrument razvoja slovenskega gospodarstva in promocije Slovenije v svetu.

Prav tako Deklaracija navaja, da je bil glede na vse tesnejše gospodarsko in varnostno-obrambno povezovanje evropskih držav tedaj strateški razvojni in varnostni interes RS vključitev v EU, ZEU in Nato. Zaradi pospeševanja gospodarskega razvoja in krepitve mednarodne vloge si je RS takrat prizadevala za aktivno ter enakopravno sodelovanje $\mathrm{v}$ pomembnejših mednarodnih organizacijah in ustanovah. Med temeljnimi vrednotami, ki naj jih zagotavlja zunanja politika RS, je bil vsekakor varen položaj v mednarodni skupnosti. RS sicer ni bila izpostavljena neposrednim varnostnim izzivom, hkrati pa so bili mogoči nepredvidljivi varnostni izzivi v prihodnjem stoletju. Dejstvo je, da je bila RS na obrobju nestabilnega območja Balkana in JVE; tudi njena sredozemska lega zahteva, da z izjemno pozornostjo dolgoročno utrjuje varnostni položaj. Kot nova država, ki ima omejeno moč, si je morala RS zagotoviti dolgoročno varnost predvsem z urejenimi odnosi s sosedi, z vključitvijo v zanesljiva zavezništva in $\mathrm{z}$ aktivnim sodelovanjem $\mathrm{v}$ sistemih kolektivne varnosti.

V sedanjih mednarodnih razmerah in tudi $\mathrm{v}$ perspektivi je tako zavezništvo Nato. Vključitev vanj je bil zato eden temeljnih strateških nacionalnih interesov Slovenije in njene zunanje politike $\mathrm{v}$ preteklem obdobju. Uresničevanje tega nacionalnega interesa, ki je bil potrjen tudi s sklepi Državnega zbora (v nadaljevanju DZ), zahteva, da RS kot partnerica aktivno sodeluje $\mathrm{z}$ Natom in se integrira $\mathrm{v}$ njegove dejavnosti ter strukture. V obdobju mednarodne stabilnosti varnost manjših držav ni vprašljiva. Vendar pa zgodovina prejšnjega stoletja potrjuje, da so v obdobjih mednarodnih kriz prav manjše države izpostavljene nevarnim varnostnim izzivom, če niso čvrsto zakoreninjene v močnih in zanesljivih zavezništvih. Z ustreznimi zunanjepolitičnimi 
odločitvami in dejanji si RS utrjuje svoj položaj Natove članice. To pomeni, da RS partnerstvo z Natom potrjuje z jasnimi zunanjepolitičnimi stališči, ukrepi in aktivnostmi. Za izpopolnjevanje partnerstva z Natom sta še posebno pomembna aktivna vloga in sodelovanje RS pri prizadevanjih za odpravo kriznih žarišč na Balkanu in v Afganistanu.

V procesu graditve nove evropske oziroma transatlantske varnostne arhitekture dobivata vse pomembnejšo vlogo tudi EU in OVSE. Včlanitev RS v EU, ki postaja ob Natu in v sodelovanju z njim pomemben dejavnik evropske varnosti, je bil prav tako strateški cilj zunanje in varnostne politike. Njegovo uresničevanje je potekalo vzporedno z vključevanjem v Nato. RS se je s svojim uspešnim razvojem in z zunanjo politiko uveljavila kot srednjeevropska država, tako pa so nastali nujni pogoji in tudi pričakovanja mednarodne skupnosti za njeno aktivno sodelovanje na kriznem območju JV. Na podlagi temeljnih vrednot in strateških interesov so prednostni cilji zunanje politike RS utrjevanje mednarodnega položaja in ugleda naše države, stabilni in dobri odnosi z vsemi državami, ki nas neposredno obdajajo, polnopravno članstvo v EU, polnopravno članstvo v Natu in EU, članstvo v OECD, aktivna vloga v OZN, OVSE, WTO, CEFTA in v odnosih z EFTA, tesnejše sodelovanje z državami Srednje Evrope v okviru SEP, v okviru trilaterale (Italija, RS, Madžarska) in drugih podobnih povezav, aktivno sodelovanje Slovenije pri stabilizaciji področja JVE in krepitev gospodarskega sodelovanja. Na podlagi geografskih, političnih, gospodarskih, kulturnih in zgodovinskih danosti lahko RS pri izvajanju svoje zunanje politike uporablja predvsem držo privrženosti temeljnim mednarodnopravnim načelom, izkazuje prizadevnost za spoštovanje temeljnih človekovih pravic doma in v svetu ter pomaga pri reševanju zapletenih razmer, tako v svoji soseščini kot drugod. RS lahko svoje nacionalne interese uveljavlja le z močjo argumentov, pri čemer lahko na uravnotežen način uporablja zavezništva držav, zvez in mednarodnih ustanov. Temeljne vrednote, po katerih se pri tem ravna, so mir, varnost, blaginja, ozemeljska celovitost in zaščita ter razvijanje nacionalne identitete. Okviri delovanja RS v mednarodnih odnosih so in vedno bodo demokracija, spoštovanje človekovih pravic in vladavina prava.

\subsection{Deklaracija o zunanji politiki Republike Slovenije}

Deklaracija v uvodu opredeljuje, da mora zunanja politika RS zagotavljati dve temeljni vrednoti: varnost in blaginjo države ter njenih državljanov in temeljne zunanjepolitične interese ter cilje, ki so temeljili na doseženem širokem političnem soglasju strank DZ.

Med drugim navaja tudi, da je primarna zunanjepolitična naloga te Deklaracije ureditev odnosov s sosednjimi državami, ki temeljijo na medsebojnem zaupanju in spoštovanju. Deklaracija poudarja, da RS sledi istim ciljem in načelom kot EU, med katerimi izstopa načelo enakopravnosti. RS je na podlagi sprejete Deklaracije usklajevala svojo zakonodajo z zakonodajo EU, da bi ustvarila pogoje za prost pretok blaga, storitev, kapitala in ljudi. Hkrati pa je želela, skladno s cilji Pogodbe o Evropski uniji (Treaty on European Union, 1992), sodelovati v procesu širjenja 
in poglabljanja integracije tudi na podlagi podpisanega Evropskega sporazuma, katerega izvajanje, skupaj s pogajanji in izvajanjem predpristopne strategije, predstavlja med seboj močno povezane dele procesa vključevanja RS v EU. Opredeljuje tudi prednostne naloge RS v okviru EU in Nata, predvsem glede na vse bolj strateško odpiranje EU do drugih evropskih držav v okviru globalizacijskih procesov. RS je temu namenila posebno pozornost in skladno s tem že pred polnopravnim članstvom podpirala skupno zunanjo in varnostno politiko EU (Deklaracija o zunanji politiki RS, 1999).

\subsection{Resolucija o strategiji nacionalne varnosti Republike Slovenije}

Resolucija o izhodiščih zasnove nacionalne varnosti RS (Uradni list RS, št. 71/1993) ni jasno opredeljevala varnostnih interesov RS, čeprav je bilo iz vsebine razvidno, da določa temeljna izhodišča nacionalne varnosti. Z dopolnilom Resolucije o izhodiščih zasnove nacionalne varnosti RS (1994) je bila dana podlaga vključevanja RS $\mathrm{V}$ evropske in druge mednarodne gospodarske ter politične povezave. RS je prevzela hkrati pravice in odgovornosti, ki jih te povezave zahtevajo na obrambnem področju, razen zagotavljanja mirovnih sil v prostoru nekdanje Jugoslavije do končanja tedanje krize. Hkrati se prvič pojavi cilj vključevanja v Nato oziroma Zahodnoevropsko unijo kot evropski steber Nata. S temi strateškimi izhodišči se je začela RS leta 1997 vključevati v prve mirovne operacije.

Resolucija o strategiji nacionalne varnosti RS (Uradni list RS, št. 56/2001) opredeli varnostni interes RS v okviru članstva v EU in Natu. Uresničevanje tega nacionalnega interesa zahteva, da se RS aktivno in vsestransko pripravlja na prevzem zavezniških nalog z akcijskim načrtom za članstvo in partnerstvo za mir. Prvič je SV jasno opredeljena kot partnerica pri izpolnjevanju ciljev zunanje politike. V Resoluciji je tudi določeno, da bo obrambni sistem v sistemu kolektivne obrambe izvajal naloge, ki jih bo prevzela RS z vključitvijo v Nato. Nosilec vojaške obrambe RS je SV. Vojaška obramba države je ob odvračanju agresije glavna naloga SV. Njene naloge so tudi izvajanje obveznosti, ki izhajajo iz sklenjenih mednarodnih pogodb, sodelovanje v operacijah v podporo miru in humanitarnih operacijah, sodelovanje v zaščiti in reševanju ob naravnih in drugih nesrečah ter izvajanje drugih nalog, določenih z zakonom.

\subsection{Strategija sodelovanja Republike Slovenije v mednarodnih operacijah in na misijah}

Strategija sodelovanja Republike Slovenije v mednarodnih operacijah in na misijah (Uradni list RS, št. 19/10) je prvi političnovarnostni in obrambno-vojaški dokument v obliki strategije sodelovanja v MOM. S tem dokumentom je presežena razpršenost strateških in političnih usmeritev glede sodelovanja v MOM ter dosežena njihova časovna aktualizacija. RS s strategijo sodelovanja v mednarodnih operacijah in na misijah določa okvire za odločanje o sodelovanju ter opredeljuje splošen nabor zmogljivosti za njegovo izvajanje. RS s strategijo opredeljuje odziv na spremembe v globalnem okolju, ki zahtevajo nove pristop, razvoj in uporabo celovitega nabora instrumentov ter aktivnosti, vključno s političnimi, diplomatskimi, civilnimi, vojaškimi, 
razvojnimi in drugimi oblikami. Pri tem so še posebno pomembni usklajeno izvajanje aktivnosti, učinkovita koordinacija, konsistentnost izvajanja politike sodelovanja $\mathrm{V}$ mednarodnih operacijah in na misijah kot tudi sodelovanje vseh akterjev na nacionalni ravni v vseh fazah sodelovanja, od načrtovanja do izvedbe. RS tako prispeva $\mathrm{k}$ vzpostavljanju in ohranjanju mednarodnega miru ter varnosti, stabilnosti, demokracije, zagotavljanju humanitarne pomoči, vzpostavljanju vladavine prava, krepitvi človekovih pravic in temeljnih svoboščin, razvoju civilne družbe, krepitvi trajnostnega razvoja v mednarodni skupnosti ter pomoči ob naravnih in drugih nesrečah, s čimer krepi tudi svojo varnost. Strategija je usklajena z drugimi pomembnejšimi dokumenti, ki urejajo področje nacionalne varnosti, zunanje politike, vključno z razvojnim sodelovanjem, drugimi strateškimi dokumenti in ustreznimi zakonodajnimi akti. Strategija določa pogoje za ustrezno opredelitev strateških in izvedbenih ciljev, krepitev analitične podpore pri odločanju, povečanje prožnosti, krepitev koordinacije za doseganje celovitega pristopa in sinergij, doseganje multiplikativnih učinkov ter za skrajšanje odzivnega časa za sprejetje nove MOM in njeno napotitev. Strategija hkrati določa pravni okvir sodelovanja RS v MOM, in sicer z Ustavo, Zakonom o Vladi, Zakonom o zunanjih zadevah, Zakonom o obrambi, Zakonom o napotitvi oseb na mednarodne civilne misije in $\mathrm{v}$ mednarodne organizacije, Zakonom o Policiji, Zakonom o varstvu pred naravnimi in drugimi nesrečami ter drugimi zakonskimi in podzakonskimi akti. Strategija sodelovanja RS v mednarodnih operacijah in na misijah predstavlja odziv na spremembe varnostnega okolja in novih globalnih izzivov, ki jih podrobneje opredeljujejo Resolucija o strategiji nacionalne varnosti RS, Strategija slovenske zunanje politike, Strategije javne varnosti, Resolucija o mednarodnem razvojnem sodelovanju RS za obdobje do leta 2015 ter Resolucija o nacionalnem programu varstva pred naravnimi in drugimi nesrečami $\mathrm{v}$ letih 2009-2015. Nastale spremembe zahtevajo razvoj celovitega nabora mehanizmov in aktivno sodelovanje $\mathrm{v}$ skupnih prizadevanjih mednarodne skupnosti za preprečevanje, obvladovanje in reševanje konfliktov, pokonfliktno obnovo na globalni ravni in pomoč ob naravnih ter drugih nesrečah. Po celoviti proučitvi Strategije lahko sklenemo, da gre za dokument, ki pomeni vez med političnimi stališči in določili za izvedbeno raven.

\subsection{Koalicijski sporazum 2008-2012}

Novembra 2008 so stranke Socialni demokrati, Zares, Demokratična stranka upokojencev Slovenije in Liberalna demokracija Slovenije sklenile koalicijski sporazum o sodelovanju v Vladi RS za mandat 2008-2012.

Najprej naj pojasnim, da koalicijska pogodba oziroma sporazum ni pravni akt, temveč gre za političen dogovor, ki ga sklenejo partnerji v Vladi. Vladne stranke zavezuje politično in zato so tudi sankcije ob morebitni kršitvi pogodbe zgolj politične. Ker je koalicijska pogodba le politična zaveza, zanjo ni pravnih sankcij, niti je ne presojajo pravni organi.

Kljub navedenemu menim, da je treba pojasniti dogovor Vlade glede politike MOM. Koalicijski partnerji so se zavezali, da bo RS sodelovala v mirovnih operacijah po 
načelih koncentracije in specializacije ter sprejemala obveznosti v operacijah, ki temeljijo na resolucijah VS OZN. Spodbujala bo dobro prakso parlamentarne razpravne vloge pri napotitvi enot in posameznikov v tujino ter okrepila medresorsko koordinacijo na področju napotitve v MOM. Koalicijski partnerji so se strinjali, da bo Vlada prednostno obravnavala odpoklic vojaških inštruktorjev iz Iraka in nadaljnjo vlogo RS v operacijah v Afganistanu. Hkrati so se zavezali za oblikovanje in pripravo jasne strategije sodelovanja SV v MOM ter povečanje vloge DZ pri pošiljanju pripadnikov SV in drugih državnih organov RS v MOM, in sicer prek širše politične podpore DZ.

Po pregledu koalicijskega sporazuma je razvidno, da bo tudi v prihodnje SV svoje naloge $v$ tujini izvajala predvsem $v$ funkciji zunanjepolitičnih interesov RS in šele nato pride do izraza varnostni interes.

\subsection{Koalicijski sporazum 2012-2015}

25. januarja 2012 so stranke Slovenska demokratska stranka, Državljanska lista Gregorja Viranta, Demokratična stranka upokojencev Slovenije, Slovenska ljudska stranka in Nova Slovenija - krščanska ljudska stranka sklenile Pogodbo za Slovenijo 2012-2015, koalicijsko pogodbo o sodelovanju v Vladi RS za mandat 2012-2015.

V 11. poglavju te pogodbe se koalicijski partnerji zavežejo, da bodo z notranjimi rezervami povečali učinkovitost obrambnega sistema. V nasprotju s koalicijskimi sporazumi v preteklosti sedanji ne omenja in določa vloge ter obsega sodelovanja SV v MOM, kar verjetno pomeni, da se trenutni obseg delovanja SV ne bo bistveno spreminjal. Posamezne spremembe pa se bodo določale glede na aktualno situacijo s sklepi Vlade RS. Prav tako ni zaslediti, da bi se način odločanja o sodelovanju na posamezni MOM spreminjal, kot je nakazoval predhodni koalicijski sporazum.

\section{MEDNARODNE MIROVNE OPERACIJE}

Mirovne operacije v najširšem pomenu besede so vse oblike vojaških in nevojaških aktivnosti, ki potekajo v okviru političnih in diplomatskih prizadevanj za vzpostavitev ter ohranjanje mednarodnega miru. Mirovne operacije so sredstvo zunanje politike od začetka devetnajstega stoletja, nov pomen pa so dobile po koncu hladne vojne, to je po letu 1989. So ena najopaznejših dejavnosti OZN, čeprav veliko operacij še vedno poteka zunaj njenega okvira. Mirovne operacije vsebujejo torej vse oblike vojaških in nevojaških aktivnosti za vzpostavitev ter ohranjanje mednarodnega miru, za katere je značilno, da imajo mednarodni mandat, ki ga po navadi odobrijo mednarodne organizacije (najbolj zaželeno je, da je to VS ZN). Mirovne operacije izvajajo mednarodne organizacije (kot ZN), regionalne organizacije (kot so Nato, EU, OVSE) ali ad hoc koalicije držav (Jelušič, 2003, str. 20, 21).

S koncem obdobja hladne vojne so svetovni mir začeli ogrožati različni verski, ekonomski in nacionalni spori v različnih delih sveta. Vzporedno s tem so se začeli večati število in obseg mirovnih operacij ter njihova zahtevnost. Klasične mirovne 
operacije vzdrževanja miru, ki so bile značilne za obdobje hladne vojne, so prerasle v kompleksne, integrirane operacije, ki vključujejo politične, vojaške in humanitarne aktivnosti.

Danes poznamo številne različne delitve mirovnih operacij. V nadaljevanju bom predstavil delitev, ki jo navaja Joint Military Doctrine (Peace support operations, 1997, str. 22) in opredeljuje tri stopnje z devetimi mednarodno priznanimi kategorijami vojaških mirovnih operacij.

1. stopnja

Aktivnosti z visokim pritiskom neoboroženih enot ali enot, oboroženih z lahkim orožjem, z manjšimi premiki.

To so:

- opazovalne misije,

- medpozicijske razmejitvene sile.

2. stopnja

Reševanje konfliktov še pred krizo v posameznih državah med različnimi narodi in vlado zahteva visoko usposobljene sile ter težje orožje kot na stopnji 1.

Aktivnosti so:

- preventivna razvrstitev sil,

- resolucijski ukrepi pri notranjih konfliktih v državi,

- sodelovanje pri začasnih ukrepih,

- zaščita humanitarne pomoči,

- zagotavljanje in prepoved gibanja.

3. stopnja

Zahteva po intenzivnih, večjih operacijah z naraščanjem nevarnosti in sodobno koordinacijo vseh vojaških prizadevanj.

To so:

- vojaško sankcioniranje,

- vojaško obnavljanje miru s silo.

Različne stopnje z več vrstami mirovnih posredovanj vključujejo:

- nadziranje prenehanja spopadov,

- demobilizacijo borcev in pomoč pri vključevanju v civilno družbo,

- zaščito prebivalstva pred agresijo,

- razoroževanje in uničenje oborožitve,

- zaščito in spremljanje beguncev ter razseljenih oseb,

- humanitarno pomoč,

- vzpostavljanje državnih institucij, civilne policije in pravnega reda,

- uveljavljanje človekovih pravic,

- spremljanje svobodnih volitev,

- vzpostavljanje varnih con in mirnih območij,

- vzpostavljanje in vzdrževanje različnih prepovedi (embarga),

- zagotavljanje pomena mandata. 
Navedena mirovna posredovanja ne veljajo le za izvajanje mirovnih operacij v okviru OZN, temveč jih sprejemajo in izvajajo tudi druge mednarodne organizacije. Raznolikost problemov, ki jih rešujemo z mirovnimi operacijami, in možen prehod $\mathrm{v}$ kratkem času iz ene $\mathrm{v}$ drugo stopnjo pa nam izvedbo mirovnih operacij še bolj otežujeta. Kljub vse večji standardizaciji mirovnih operacij nam njihovo izvedbo otežujejo tudi udeleženci, tako države kot tudi posamezniki, saj prihajajo iz različnih okolij, ki so na različnih stopnjah družbenega razvoja. Največjo težavo predstavljajo nejasni mandati, ki so kompromis držav članic VS ZN in mednarodne skupnosti.

\subsection{Vključevanje držav v mirovne operacije}

Posamezne države se v mirovne operacije vključujejo iz različnih nagibov. Še posebno je odločitev za udeležbo v mirovnih operacijah težavna za manjše države, ki so omejene z viri na vseh področjih. Kljub temu lahko razvrstimo nekatere nagibe, ki posamezne države vodijo k odločitvi za vključevanje v mirovne operacije (Future place operations achieving success, NATO Defence College, 1997, str 38), v te skupine:

\section{Politični cilji}

Mirovne operacije pod pokroviteljstvom mednarodne skupnosti lahko dajejo rezultate pri doseganju političnih ciljev, ki jih država posamezno ne more doseči oziroma jih lahko doseže v daljšem časovnem obdobju. Seveda pa je treba opozoriti, da so taki politični cilji sprejemljivi le, če so v okviru pravne ureditve OZN. Morebitne drugačne ambicije so neproduktivne.

\section{Ugled države}

Mednarodne mirovne operacije, ne glede na način vključevanja, vsem udeležencem v mednarodnem smislu dvigujejo ugled in pomen v mednarodni skupnosti, kar je še posebno zanimivo in pomembno za manjše države.

\section{Vojaško urjenje in pridobivanje izkušenj}

Mirovne operacije omogočajo neposredne, odlične pogoje za vojaške enote $\mathrm{v}$ širokem spektru vojaških in humanitarnih situacij. Tako urjenje omogoča hiter napredek pri vzpostavljanju bojne pripravljenosti, ki je pomembna tudi za nacionalno varnost. Pravzaprav je nekatere situacije oziroma pogoje, v katerih se lahko znajdejo oborožene sile, nemogoče simulirati v drugačnih pogojih urjenja.

\section{Finančni prihranki}

Čeprav so mirovne operacije zelo drage, pa so vendarle cenejše, kot so stroški posameznih držav v primeru preraščanja kriznih situacij v popolne konflikte. To še posebno velja za manjše države. OZN vzpostavlja posebne standarde stroškov posameznih operacij in prav gotovo je delež stroškov za vojaka posamezne države glede na pogoje dela nižji, kot je sicer. 


\subsection{Delitev mirovnih operacij}

Klasifikacija oziroma načelna delitev mirovnih operacij nam kaže na kompleksnost in raznolikost nalog, s katerimi se srečuje mednarodna skupnost pri izvajanju MOM. Pojav različnih klasifikacij (Peace support operations, 1997, str. 18) pri organizatorjih in nastajanje novih operacij (Future place operations achieving success, NATO Defence College, 1997, str. 33) pa dokazujeta, da so naloge, opredeljene v takih operacijah, težko ločljive. So pretežno daleč od klasičnih vojaških nalog, bližje policijskim nalogam, hkrati pa lahko izredno hitro prerastejo v časovno omejene zahtevne vojaške operacije z visoko stopnjo dinamike. Načelno pa lahko na podlagi vsake delitve, ne glede na organizatorja, ugotovimo, da gre na eni strani za vzdrževanje miru (peace keeping) in na drugi strani za uveljavljanje miru (peace enforcement). Poleg zgoraj navedenih mirovnih operacij za vzdrževanje in uveljavljanje miru poznamo še operacije preventivne diplomacije, operacije za ustvarjanje miru ter operacije za graditev miru (Jelušič, 2003, str. 20).

SV je do zdaj sodelovala le v operacijah vzdrževanja miru, vendar je zaradi aktivnega vključevanja RS v mednarodne integracije in usposobljenosti, opremljenosti ter izkušenj pripadnikov SV, ki so jih dokazali v vseh mirovnih operacijah, ki so se jih udeležili, mogoče pričakovati tudi sodelovanje $v$ drugih prej naštetih oblikah mirovnih operacij.

\section{NORMATIVNOPRAVNA UREDITEV KOLEKTIVNE VARNOSTI}

OZN je bila od ustanovitve glavna organizatorka mirovnih operacij. Čeprav danes mirovne operacije za vzdrževanje miru najpogosteje povezujemo z OZN, pa ta tehnika dokončanja konfliktov in vzpostavitve miru ni omenjena v Ustanovni listini $\mathrm{ZN}$, temeljnem ustanovitvenem aktu te organizacije. Ob ustanovitvi OZN je bilo predvideno, da bodo velike sile tako imenovanih stalnih pet članic VS imele vodilno vlogo pri ohranjanju mednarodnega miru in varnosti. V šestem poglavju Ustanovne listine $\mathrm{ZN}$ so od 33. do 38. člena predvideni mehanizmi mirnega reševanja sporov, kot so pogajanja, anketa, posredovanje, sprava, sodna rešitev in druga mirna sredstva po izbiri strank v sporu. To so diplomatsko-pravna sredstva. V sedmem poglavju Ustanovne listine $\mathrm{ZN}$ so predvidene od 39. do 51. člena akcije ob morebitnem ogrožanju miru, kršitvi miru in agresivnih dejanjih. Ukrepi se nanašajo na sankcije in prisilne akcije. Izkaže se, da mirovne operacije za vzdrževanje miru ne spadajo v nobeno izmed zgoraj omenjenih kategorij, zato jih nekateri umeščajo med šesto in sedmo poglavje Ustanovne listine Združenih narodov ali celo menijo, da so predpisane v tako imenovanem šestem-in-pol poglavju Ustanovne listine ZN. Tega poglavja ni, le aktivnosti ohranjanja miru so take, da so vmes med diplomatsko-pravnimi, vendar povsem nevojaškimi in nenasilnimi sredstvi reševanja sporov ter vojaškimi nasilnimi sredstvi reševanja mednarodnih sporov (Jelušič, 2003, str. 22).

Operacije za ohranjanje miru, kot se razvijejo od leta 1947, predvsem med hladno vojno, so izraz nesposobnosti VS ZN, da bi s soglasjem vseh stalnih članic oblikoval 
klasične operacije za uveljavljanje miru, kot jih je predvidevalo sedmem poglavje Ustanovne listine ZN.

Priprava in izvedba mirovnih operacij, v katere se vključujejo oborožene sile različnih držav, zahtevata tudi vrsto dokumentov, s katerimi se določijo pristojnosti in odgovornosti vseh udeležencev. Ti dokumenti so po pomenu, strukturi in vsebini zelo različni, odvisno od dejavnikov posamezne operacije. Pri izvedbi mirovnih operacij, pri kateri gre po njihovi naravi za visoko politično, vojaško in humanitarno mednarodno dejavnost, pa so se izoblikovali nekateri pomembni temeljni dokumenti. Navajam dokumente, ki jih določa OZN, vendar jih uporabljajo v celoti ali vsaj deloma tudi druge organizacije, ki izvajajo mirovne operacije. Ti dokumenti so (Peace support operations, 1997):

- Mandat oziroma zaupnica OZN,

- Sporazum o sodelovanju sil (MOU),

- Dogovor o statusu sil (SOFA),

- 1994. konvencija o varnosti OZN in osebja članic,

- Pogoji napotitve (TOR),

- Pravila uporabe (ROE),

- Dogovor o tranzitu (TA),

- drugo.

\section{PRAVNI VIDIKI SODELOVANJA RS V MOM}

Ministrstvo za zunanje zadeve vodi postopek usklajevanja in prouči dano pobudo sodelovanja RS v mednarodnih operacijah in na misijah. Sekretariat Sveta za nacionalno varnost pobudo dopolni z oceno tveganja in ustvari mnenje. Usklajen in dopolnjen predlog, ki vsebuje obrazložitev, vključno z jasnim ciljem prispevka in legitimnim mednarodnim mandatom, oceno najprimernejšega nabora mehanizmov, aktivnosti in potrebnih virov, opredelitev pričakovanih učinkov, obveščevalno-informativno in obveščevalno-varnostno podporo ter z oceno varnostnega tveganja, obravnavajo Ministrstvo za zunanje zadeve, Ministrstvo za obrambo in Ministrstvo za notranje zadeve na ministrski ravni oziroma ravni državnih sekretarjev. Ministrstvo za zunanje zadeve in pristojno ministrstvo posredujeta usklajen in dopolnjen predlog v odločitev Vladi RS.

Trenutne pravne podlage v RS, ki urejajo pravno področje vključevanja pripadnikov SV v mirovne operacije:

- Ustanovna listina Združenih narodov in resolucija Varnostnega sveta,

- Ustava RS,

- Zakon o obrambi,

- Zakon o službi v SV,

- Zakon o zunanjih zadevah,

- Vojaška doktrina,

- Strategija sodelovanja Republike Slovenije v mednarodnih operacijah in na misijah, 
- za posamezno operacijo sprejet sklep Vlade RS o napotitvi enot SV v mirovno operacijo,

- za posamezno operacijo sprejete mednarodne pogodbe in drugi izvedbeni akti,

- odredba ministra za obrambo o napotitvi pripadnikov SV v MOM, izdana na podlagi sprejetega sklepa Vlade RS,

- uredbe in pravilniki, ki urejajo delovnopravni status pripadnika pri opravljanju nalog v tujini,

- formacija enote.

RS je kot članica OZN že aktivno sodelovala $\mathrm{v}$ akcijah v podporo miru na podlagi odločitev Generalne skupščine ali VS te organizacije in bo sodelovala tudi $\mathrm{V}$ prihodnje, če bi bilo to nujno, skladno s svojimi zmožnostmi. Na podlagi resolucije VS ZN, ki na podlagi določb Ustanovne listine OZN (sedmo poglavje) sprejme odločitev o izvedbi ukrepov proti neki državi, vključno z uporabo sile, sprejme odločitev o sodelovanju SV pri izvedbi ukrepov Vlada RS, in sicer z uporabo 84. člena Zakona o obrambi.

Vlada RS tako na podlagi tretjega odstavka 84. člena Zakona o obrambi (Uradni list RS, št. 103/2004 - ZOBr - UPB-1) odloča o sodelovanju SV pri izpolnjevanju obveznosti, prevzetih $\mathrm{v}$ mednarodnih organizacijah, skladno z mednarodnimi pogodbami. V primeru OZN je treba kot mednarodno pogodbo šteti Ustanovno listino OZN, ki zavezuje tudi RS. Ob upoštevanju določb Ustanovne listine, ki urejajo pooblastila VS, predvsem sedmo poglavje, lahko ugotovimo, da resolucija VS, ki odobrava uporabo sile proti neki državi, vsekakor predstavlja obveznost iz 84. člena Zakona o obrambi in petega odstavka 75. člena Zakona o zunanjih zadevah. Posebne dogovore za izvedbo sodelovanja, če bi bili nujni, pa bi ratificirala Vlada RS na podlagi petega odstavka 75. člena Zakona o zunanjih zadevah.

Ustava RS opredeljuje v 8. členu, da morajo biti zakoni in drugi predpisi skladni s splošno veljavnimi načeli mednarodnega prava in z mednarodnimi pogodbami, ki obvezujejo RS. Ratificirane in objavljene mednarodne pogodbe se uporabljajo neposredno. Formalne pogoje sodelovanja določa Zakon o obrambi, še posebno novela zakona, ki je začela veljati 13. junija 2002. Glede na to, da Zakon o obrambi večkrat omenja mednarodno pogodbo, je treba pri postopku priprave mednarodnega sodelovanja upoštevati določbe Zakona o zunanjih zadevah (peto poglavje).

Pristojnost glede odločitve za uporabo SV se na podlagi Zakona o obrambi deli med Državni zbor RS in Vlado RS, v izjemnih primerih ima to pristojnost tudi predsednik republike. Zakon o zunanjih zadevah (Uradni list RS, št. 45/01) opredeljuje sklepanje pogodb v petem poglavju zakona, tako da izrecno omogoča oziroma lajša postopek ratifikacije tistih mednarodnih pogodb s področja obrambe, ki pomenijo izvedbo prevzetih obveznosti ali sprejetih odločitev o mednarodnem sodelovanju RS (75. člen). Hkrati pa tudi opredeljuje nepogodbene mednarodne akte (zapisniki, programi sodelovanja idr.), ki jih zaradi izvajanja mednarodnih pogodb sklenejo s temi pogodbami ustanovljena skupna telesa in s katerimi pogodbenice ne prevzemajo 
novih pravnih obveznosti. S temi akti se Vlada samo seznani - informacija se sporoči Vladi, ki pa za podpis hkrati pooblasti predlagano osebo.

Za sodelovanje SV v mirovnih operacijah morajo biti izpolnjene te zahteve:

- resolucija Varnostnega sveta $\mathrm{z}$ mandatom,

- mednarodna pogodba, izpolnjevanje obveznosti v mednarodnih organizacijah,

- izvedbeni akti (Memorandum o sodelovanju, Tehnični dogovor).

Če obstaja resolucija VS, odloča Vlada RS na podlagi 84. člena ZoObr o uporabi SV. Ustrezen dogovor ratificira Vlada, mogoča pa je tudi začasna uporaba dogovora od dneva podpisa na podlagi Zakona o zunanjih zadevah.

Poleg navedenih temeljnih mednarodnih in nacionalnih dokumentov, ki so podlaga za pripravo in uspešno izvedbo mirovne operacije, pa morajo posamezne države sprejeti več normativnih aktov, ki jim omogočajo pravilno in hitro vključevanje v mirovne operacije. Vlada RS je leta 2009 sprejela Strategijo sodelovanja RS v MOM, ki omogoča celovit pristop RS na področju MOM.

GŠSV je na podlagi zgoraj navedenega akta izdelal direktivo za načrtovanje in pripravo zmogljivosti SV za sodelovanje v MOM. Namen direktive je opredelitev procesov, postopkov in načrtovanja na strateški in operativni ravni za sodelovanje SV v MOM. Z direktivo se zagotavljajo enotnost načrtovanja, organiziranja, izvajanja priprav in učinkovito poveljevanje ter kontrola med sodelovanjem SV v MOM.

Cilji direktive so:

- opredelitev načina načrtovanja in priprava zmogljivosti SV za sodelovanje v MOM,

- opredelitev načina zastopanja interesov SV na vojaškem področju v mednarodnem okolju oziroma v operacijah, v katerih naj bi SV sodelovala oziroma že sodeluje,

- vzpostavitev učinkovitega načina dela in sodelovanja z organi MO, da bi se usklajeno zastopali nacionalni interesi ter interesi SV v mednarodnem okolju,

- zagotovitev nujnih informacij predstavništev SV v tujini (PSV), da bodo sposobna aktivno in učinkovito delovati skladno z nacionalnimi cilji, usmeritvami in sprejetimi obveznostmi,

- vzpostavitev procesov učinkovitega sodelovanja med Generalštabom slovenske vojske (GŠSV), Poveljstvom za doktrino, razvoj, izobraževanje in usposabljanje (PDRIU), Poveljstvom sil Slovenske vojske (PSSV in PSV),

- zagotovitev učinkovitega pretoka in obdelave informacij ter dokumentov. 


\section{SODELOVANJE SV V MIROVNIH OPERACIJAH}

\subsection{Namen SV}

Ustava RS ne določa jasno namena SV. Z namenom vojske se lahko povezujejo: 4. člen ustave, ki govori o »ozemeljsko enotni in nedeljivi državi«, 5. člen, ki določa, da »država ustvarja možnosti za skladen civilizacijski in kulturni razvoj Slovenije« in 124. člen, ki določa, da »vrsto, obseg in organizacijo obrambe, nedotakljivosti in celovitosti državnega ozemlja ureja zakon, ki ga sprejme državni zbor z dvotretjinsko večino glasov navzočih poslancev«. 124. člen prav tako določa, da »država pri zagotavljanju varnosti izhaja predvsem iz mirovne politike ter kulture miru in nenasilja $\ll$.

Zakon o obrambi v 2. členu govori o namenu obrambe in določa, da je »temeljni namen obrambe odvračanje napada na državo ter obramba neodvisnosti, nedotakljivosti in celovitosti države«. Isti člen tudi navaja, da se »ta namen uresničuje tudi $\mathrm{z}$ vključevanjem in $\mathrm{z}$ aktivnim sodelovanjem države $\mathrm{v}$ mednarodnih varnostnih povezavah na podlagi mednarodnih pogodb«.

To pomeni, da je namen obrambe, in s tem tudi SV, zagotavljanje suverenosti in neodvisnosti RS z obrambo njene ozemeljske nedotakljivosti ter celovitosti, ki se uresničuje s preprečevanjem in obrambo proti vsaki vrsti agresije, vojaškim prispevanjem $\mathrm{k}$ mednarodnemu miru in stabilnosti ter sodelovanjem vojske pri zagotavljanju varnosti in blaginje državljanov. ${ }^{1}$

\subsection{Naloge SV}

Zakon o obrambi določa naloge SV:

- izvaja vojaško izobraževanje in usposabljanje za oborožen boj ter druge oblike vojaške obrambe;

- zagotavlja potrebno ali zahtevano pripravljenost;

- ob napadu na državo izvaja vojaško obrambo;

- ob naravnih in drugih nesrečah skladno s svojo organizacijo in opremljenostjo sodeluje pri zaščiti in reševanju;

- izpolnjuje obveznosti, ki jih je država sprejela v mednarodnih organizacijah in z mednarodnimi pogodbami;

- lahko sodeluje s policijo pri širšem varovanju državne meje v notranjosti državnega ozemlja skladno z načrti in po predhodni odločitvi Vlade, pri čemer pa pripadniki SV pri opravljanju teh nalog nimajo policijskih pooblastil.

Zakon o službi v SV v odnosu do Zakona o obrambi ne dodaja novih nalog, temveč v 22. členu podrobneje opredeli, kaj vsebuje izpolnjevanje obveznosti, ki jih je država sprejela v mednarodnih organizacijah in z mednarodnimi pogodbami.

SV te obveznosti izpolnjuje:

\footnotetext{
S predlagano spremembo definicije namena so natančneje določeni temelji za naloge SV v klasični obrambi države, njeni mednarodni vlogi ter njeni podpori drugim državnim organom, tako na področju zaščite in reševanja kot na področju pomoči drugim državnim organom, na primer Policiji ali obalni straži.
} 
- z delovanjem vojaške diplomacije;

- s sodelovanjem v operacijah, na misijah in v drugih oblikah delovanja, primernih za preprečevanje sporov, ohranjanje, vsiljevanje in vzdrževanje miru ter v kolektivni obrambi;

- s sodelovanjem in delovanjem $\mathrm{v}$ skupnih poveljstvih in enotah zavezništva oziroma drugih mednarodnih organizacij;

- s sodelovanjem in delovanjem v organih, predstavništvih ali službah mednarodnih organizacij;

- $\mathrm{s}$ sodelovanjem in delovanjem $\mathrm{v}$ skupnih poveljstvih in enotah, ustanovljenih $\mathrm{z}$ drugimi državami;

- z omogočanjem vojaške pomoči v oborožitvi, vojaški opremi ali v drugi obliki;

- z omogočanjem humanitarne pomoči ali pomoči za izvajanje humanitarnih dejavnosti;

- s sodelovanjem v dejavnostih za preprečevanje terorističnih in drugih pojavov ogrožanja stabilnosti ter varnosti.

\subsection{Sodelovanje enot in posameznikov SV v MOM}

Od leta 1997 RS s svojimi vojaškimi enotami aktivno sodeluje v mirovnih operacijah v tujini. Tako želi skladno s svojimi zmožnostmi in interesi prispevati k vzpostavitvi miru in stabilnosti v svetu, predvsem v svoji soseščini in JVE. Vzroki oziroma razlogi za začetek vključevanja RS in s tem posledično tudi SV v mirovne operacije so (Prezelj, 2003):

- stopnja razvoja SV,

- sindrom bežanja od Balkana,

- proces približevanja mednarodnim integracijam, še posebno Natu,

- zorenje nacionalnega interesa.

Na podlagi izkušenj prvih vključevanj pripadnikov SV v mirovne operacije v tujini lahko ugotovimo, da je bilo vključevanje v prve mirovne operacije najprej politična odločitev, ki je bila sprejeta hitro, brez celovite strokovne analize in pod velikim vplivom naše želje po vključitvi v Nato. Politični odločitvi so sicer sledile zelo intenzivne priprave $\mathrm{v}$ okviru MO oziroma SV, ki pa niso bile materialno, finančno in kadrovsko podprte. Politični odločitvi na državni ravni niso sledili državna materialna in kadrovska podpora, več dodatnih finančnih sredstev, dodatno zaposlovanje, celostna pravna ureditev itn. Vključevanje v prve mirovne operacije je bil v bistvu velik organizacijski, finančni in izvedbeni izziv.

Hkrati se poraja dilema, ali SV sodeluje v mirovnih operacijah zaradi potrebe zunanje politike ali zaradi nacionalne varnosti. Sodelovanje v mirovnih operacijah je zlasti pomembno za SV, saj tako urjenje omogoča hiter napredek pri vzpostavljanju bojne pripravljenosti, ki je pomembna tudi za nacionalno varnost, in zaradi urjenja posameznih situacij, v katerih se lahko znajdejo oborožene sile ter jih ni mogoče simulirati v drugačnih pogojih urjenja. Delovanje v tujini sta bila za slovenske oborožene sile, ki so se razvile na podlagi doktrine teritorialne obrambe, in za državo popolnoma nova naloga in nov izziv. Čeprav se je v preteklosti v nekdanji državi Jugoslaviji nekaj 
posameznih vojakov slovenske narodnosti udeleževalo mirovnih operacij v tujini, pa to niso bile sistemske izkušnje. Hkrati pa je tudi res, da teh ljudi niso aktivno vključili v priprave prvih mirovnih operacij v SV.

Glede na dejstvo, da je vključevanje v mirovne operacije postala popolnoma nova kategorija delovanja SV, se je v SV poskušal postopoma ustvariti sistem zbiranja in analiziranja pridobljenih izkušenj pripadnikov SV, ki so sodelovali v posamezni operaciji, vendar za zdaj le delno uspešno. Zato se vedno znova pojavljajo organizacijska in vsebinska vprašanja, ki so bila že rešena, vendar nikjer evidentirana ter arhivirana.

\subsection{Presek sodelovanja SV v MOM}

V dosedanjem trinajstletnem sodelovanju SV v MOM (Furlan, Jazbec, 2009) je SV sodelovala $\mathrm{v}$ devetnajstih MOM na treh kontinentih. SV je na podlagi sklepov Vlade RS nenehno povečevala svoj prispevek na kriznih žariščih, vrhunec pa je do zdaj doživela leta 2007, ko smo napotili celotni bataljon (bojno skupino SOKOL) in prevzeli območje odgovornosti ter se neposredno vključili v Kforjev sistem poveljevanja in kontrole.

Oktobra 2012 je bilo v MOM 430 pripadnikov SV na devetih misijah.

Po dostopnih podatkih je do zdaj v MOM sodelovalo 7580 pripadnikov SV in MO (PSSV, maj 2012).

Poleg pripadnikov SV sodelujejo v MOM tudi pripadniki Policije in civilni funkcionalni strokovnjaki (CFS).

Pripadniki Policije so začeli sodelovati na mirovnih misijah leta 1997 v okviru obrambne organizacije Zahodnoevropske unije na misiji MAPE v Albaniji. Trenutno na petih misijah sodeluje 21 policistov. Do zdaj je skupaj sodelovalo 287 policistov, in sicer na štirinajstih različnih mirovnih misijah do trideset policistov na leto (http:// www.policija.si/index.php/mednarodno-sodelovanje/mednarodne-civilne-misije).

Od februarja 2007 je bilo izvedenih 20 napotitev CFS z 18 CFS (http://www.mo.gov. si/fileadmin/mo.gov.si/pageuploads/revija_sv/2012/sv12_07.pdf).

Posebno pozornost pri pregledu dosedanje udeležbe SV v MOM sem namenil pregledu sklepov Vlade RS in odzivom javnosti na njihov sprejem. Slovenska javnost kot tudi politika je do leta 2006 podpirala udeležbo SV v MOM.

Prve večje polemike in strokovne debate so se začele, ko je Vlada 12. januarja 2006 sklenila, da bo RS v okviru misije Nato za usposabljanje iraških varnostnih sil v Irak napotila štiri pripadnike, in sicer tri podčastnike in častnika.

V nadaljevanju je žarišče polemik, tako političnih elit kot tudi strokovne javnosti, postajala mirovna operacija in misija Isaf v Afganistanu, v kateri SV sodeluje od 
februarja 2004. Vrhunec pa je razprava o delovanju SV v Afganistanu doživela ob odločitvi o napotitvi pripadnikov SV v Isaf v okviru svojega operativnega tima za mentorstvo in povezavo (OMLT). Vlada je odločitev sprejela na podlagi strokovnih posvetovanj doma in zlasti v okviru Nata. Skupni cilj vseh polemičnih razprav je prekinitev sodelovanja SV v operaciji Isaf ter umik enot z nemirnega območja. Vlada je sprejela odločitev, da SV sodeluje z OMLT do leta 2012 in da leta 2011 preveri možnosti nadaljevanja oziroma konca operacije. Leta 2012 je bila sprejeta odločitev, da se SV iz MOM Isafa umakne leta 2014, ko naj bi se zaključila tudi celotna mednarodna operacija Isaf.

Vzporedno s to pobudo je potekala tudi pobuda o povečani vlogi DZ RS pri odločanju o novih MOM oziroma o bistvenih spremembah, bodisi povečanju ali zmanjšanju števila pripadnikov ter pri morebitnih spremembah mandata posamezne MOM. Tako bi tovrstne politične in operativne odločitve pridobile široko politično podlago, vendar novi koalicijski sporazum 2012-2015 te spremembe ne omenja več.

V raziskavi Slovensko javno mnenje 2005, 2007, 2009 so na vprašanje: »V katere predele sveta naj bi slovenska država pošiljala vojake in policiste $\mathrm{v}$ mirovne operacije?« odgovorili tako:

\begin{tabular}{|c|c|l|c|c|c|}
\hline \multicolumn{1}{|l|}{ Tabela } & Območje MOM, na katerem je SV & SJM052 & SJM071 & SJM092 \\
\cline { 2 - 6 } & \multicolumn{1}{|l|}{ v države na ozemlju nekdanje Jugoslavije } & 39,7 & 35,0 & 36,7 \\
\hline 2 & v Afganistan & 10,1 & 8,7 & 10,9 \\
\hline 3 & v afriške države (na primer Čad, Sudan) & 13,5 & 10,4 & 12,2 \\
\hline 4 & $\begin{array}{l}\text { na Bližnji vzhod (na primer Libanon, palestinska Ozemlja - Zahodni } \\
\text { breg, Gaza) }\end{array}$ & 11,2 & 6,8 & 11,0 \\
\hline 5 & ne vem, b.o. & 53,5 & 61,6 & 57,2 \\
\hline
\end{tabular}

Vir: Malešič, Marjan, Malnar, Brina, Toš, Niko in skupina. Slovensko javno mnenje 2009/2: Raziskava o nacionalni in mednarodni varnosti [datoteka podatkov]. RS, Ljubljana: Fakulteta za družbene vede, Center za raziskovanje javnega mnenja in množičnih komunikacij [izdelava], 2009. RS, Ljubljana: Univerza v Ljubljani, Arhiv družboslovnih podatkov [distribucija], 2010.

Iz rezultatov je razvidna podpora javnosti posameznim MOM glede na območje delovanja. Primerjava za Isaf z navedenimi polemikami ni mogoča, ker je bila raziskava leta 2009 izvedena pred sprejeto odločitvijo o napotitvi OMLT. Lahko pa zasledimo zelo nizko podporo javnosti za delovanje SV v Afganistanu.

Sklep RS se za sodelovanje v MOM odloča in v njih sodeluje skladno z veljavnim pravnim okvirom, med drugim Ustavo, Zakonom o Vladi, Zakonom o zunanjih zadevah, Zakonom o obrambi, Zakonom o napotitvi oseb v mednarodne civilne misije in mednarodne organizacije, Zakonom o policiji, Zakonom o varstvu pred naravnimi in drugimi nesrečami ter drugimi bistvenimi zakonskimi in podzakonskimi akti. 
Sodelovanje SV v MOM poteka izključno na podlagi resolucij Varnostnega sveta OZN in se izvaja skladno z Ustanovno listino OZN, skupno zunanjo ter varnostno politiko EU, upoštevajoč strateški koncept Nata in cilje OVSE ter Sveta Evrope. Sodelovanje vojaških zmogljivosti RS v mednarodnih operacijah in na misijah sledi načelom enovitega nabora sil kot tudi usmerjenega ter koncentriranega vključevanja na krizna območja ob upoštevanju celovitega nacionalnega pristopa in izrabe nacionalnih prednosti. Sodelovanje se načrtuje v smislu zmerne geografske razpršenosti in večje specializacije pri zagotavljanju določenih nišnih zmogljivosti.

Sodelovanje SV za vse vrste MOM, razen za mednarodne reševalne operacije, se načrtuje skladno s prioritetnim vrstnim redom, določenim v Strategiji sodelovanja RS v mednarodnih operacijah in na misijah.

Predpostavko, da je SV primerna partnerica izvrševanja zunanje politike RS S svojim sodelovanjem v mirovnih silah $\mathrm{ZN}$ in v večnacionalnih silah Nata za mirovne operacije (pod mandatom OZN), da aktivno pomaga pri vzdrževanju in ohranjanju mednarodnega miru ter varnosti in da enote SV od leta 1997 aktivno sodelujejo v mirovnih operacijah ter uspešno izpolnijo vse naloge, ki jim jih Vlada RS določi s sklepi za vključevanje v mirovne operacije, lahko potrdim.

Delovanje RS v mednarodnih operacijah bo predvsem v funkciji varnostnih in zunanjepolitičnih interesov ter ciljev RS. SV bo zato delovala predvsem v mednarodnih operacijah z višjo stopnjo tveganja, ki zahteva poudarjeno vojaško komponento, in ne več predvsem v operacijah, ki so bližje policijskim nalogam, kar je bilo razvidno po pregledu koalicijske pogodbe. Hkrati pa zasledimo, da je in bo tudi v prihodnje SV svoje naloge $\mathrm{v}$ tujini izvajala predvsem $\mathrm{v}$ funkciji zunanjepolitičnih interesov RS, ki so večinoma prepleteni tudi z varnostnimi interesi. SV mora kot instrument politike izpolnjevati svoje zunanjepolitične cilje tudi, kadar gre za sodelovanje $\mathrm{v}$ MOM. Pri tem je treba poudariti, da sta tako zunanjepolitični kot tudi varnostni interes močno povezana z Natom in EU ter iz njih izhajajočih obveznosti zagotavljanja kolektivne obrambe in kolektivne varnosti.

Tezo, ki opredeljuje, da vključevanje SV v mednarodne operacije zahteva politični konsenz, lahko le delno potrdim, kajti vključevanje SV v MOM je postalo predmet tako političnih polemik kot tudi javnosti. Začelo se je s sklepom Vlade o napotitvi štirih pripadnikov SV v okviru Natove misije za usposabljanje iraških varnostnih sil v Irak in nadaljevalo z delovanjem SV v Afganistanu ter doseglo vrhunec ob odločitvi o napotitvi OMLT v Isaf 14 leta 2010.

V prispevku sem poskušal predstaviti tudi trditev, da v mirovnih operacijah lahko uspešno sodelujejo le visoko usposobljene in motivirane enote, kar pa je do zdaj SV uspešno dokazovala. Kot utemeljitev te trditve navajam dejstvo, da do danes v mirovnih operacijah še nismo imeli žrtev ne v nesrečah ne v bojnih spopadih. 
1. Direktiva o organiziranju in delovanju predstavništev in predstavnikov SV v tujini, 2009. Ljubljana: $G \dot{S} S V$.

2. Direktiva za načrtovanje in pripravo zmogljivosti Slovenske vojske za sodelovanje v mednarodnih operacijah in misijah, 2010. Ljubljana: GŠSV.

3. Furlan, B. in drugi, 2006. Vojaška doktrina. Ljubljana: PDRIU.

4. Future place operations acheving success, 1997. Rim: NATO Defence College.

5. Grizold, A., 1999. Evropska varnost. Ljubljana: FDV.

6. Grizold, A., Ferfila, B., 2000. Varnostne politike velesil. Ljubljana: FDV.

7. Jazbec, M. in drugi, 2002. Primerna zunanja politika. Ljubljana: MZZ, center za raziskave.

8. Jelušič, L., 2003. Mirovne operacije, I. del. Ljubljana: MO RS/Revija SV.

9. Jelušič, L., ur., 2005. Mirovne operacije in vloga Slovenije. Ljubljana: FDV.

10. Obrambna strategija RS, Vlada RS, št. 820-00/2001-1, z dne 20. 12. 2001.

11. Peace support operations, 1997, Joint Military Doctrine.

12. Podbregar, I., 2000. Interoperabilnost kadrov manjših držav v mirovnih operacijah. Ljubljana: FO V: doktorska disertacija.

13. Podbrežnik, B., 2003. Sodelovanje Slovenske vojske v mirovnih operacijah v obdobju med leti 1997 in 2002. Ljubljana: FDV, diplomska naloga.

14. Pravila službe v SV, Uradni list RS, št. 84/09.

15. Prezelj, I., 2003. Mednarodne operacije za podporo miru. Gornja Radgona: razprava na posvetu.

16. Resolucija o izhodiščih zasnove nacionalne varnosti RS, Uradni list RS, št. 71/93 in 2/94.

17. Resolucija o splošnem dolgoročnem programu razvoja in opremljanja Slovenske vojske do leta 2025 (ReSDPROSV 2025), Uradni list RS, št. 99/10.

18. Resolucija o strategiji nacionalne varnosti RS, Uradni list RS, št. 56/01.

19. Resolucija o strategiji nacionalne varnosti RS, Uradni list RS, št. 27/10.

20. SKUPINA AVTORJEV, 1993. International Military and Defence Encyclopedia. Washington: Brassey's (US).

21. Strategija sodelovanja Republike Slovenije v mednarodnih operacijah in misijah, Uradni list RS, št. 19/10.

22. UN Military Observers Handbook, 1994, United Nations.

23. Ustava RS, Uradni list RS, št. 33/91 s spremembami in dopolnitvami.

24. Ustanovna listina Združenih narodov in Statut meddržavnega sodišča, 1977, New York: Urad za javne informacije (ZN).

25. Zakon o obrambi. Uradni list RS, št. 82/94, s spremembami in dopolnitvami.

26. Zakon o službi v Slovenski vojski (ZSSloV). Uradni list RS, št. 68/2007, 58/08.

27. Zakon o zunanjih zadevah. Uradni list RS, št. 45/01, s spremembami in dopolnitvami.

28. http://www.gov.si/vrs/ (7. 5. 2012).

29. http://www.mo-rs.si/ (7. 5. 2012).

30. http://www.mors.si/fileadmin/mors/pdf/publikacije/zbornik_f.pdf. (10. 4. 2012-7. 5. 2012).

31. http://www.policija.si/ (10. 11. 2010-10. 12. 2010).

32. http://www.slovenskavojska.si/fileadmin/slovenska_vojska/pdf/bilten_sv/bilten_sv_12_3. pdf (10. 4. 2012-7. 5. 2012).

33. http://www.slovenskavojska.si/fileadmin/slovenska_vojska/pdf/bilten_sv/bilten_sv09_11_1. pdf (10. 4. 2012-7. 5. 2012). 